УДК 37.018.265:373.037

DOI:

Ірина Купчак, кандидат медичних наук, асистент кафедри акушерства і гінекології Інституту післядипломної освіти

Івано-Франківського національного медичного університету

Назар Матвійків, кандидат медичних наук, асистент кафедри акушерства і гінекології Інституту післядипломної освіти Івано-Франківського національного медичного університету

\title{
ФОРМУВАННЯ ЗДОРОВОГО СПОСОБУ ЖИТТЯ ДІТЕЙ - ПЕРШОЧЕРГОВЕ ЗАВДАННЯ БАТЬКІВ
}

Сьогоднішній стан здоров'я населення України експерти оцінюють як загрозливий. Щоб вийти з иього стану потрібні зміни у соціальній політиці держави, а також спільні дії педагогів, батьків та громадськості. У статті досліджуються шляхи і методи подолання деяких факторів сучасності, які негативно впливають на здоров'я дітей, зокрема, надмірного користування дітьми електронниими пристроями, нераціонального харчування, брак у них почуття родинності тощя. Корисним для батьків буде перелік тем для проведення санітарно-просвітницької роботи з дітьми. У зв'язку із введеням у дію Санітарного регламенту загальноосвітніх закладів істотно змінюються завдання батьків і батьківських комітетів щуодо контролю за реалізацією иъьго документа, який суттєво впливає на формування здорового способу життя дітей. Досліджується проблема стимулювання громадян Украӥни, які дотримуються здорового способу життя.

Ключові слова: здоровий спосіб життя; стан здоров'я населення; санітарно-просвітницька робота; Конвенція ООН про права дитини; програма “Діти України”; електронні пристрої; рачіональне харчування; родинність; здорові навички; Санітарний регламент шкіл; соиіально-економічне стимулювання.

Jim. 20.

Iryna Kupchak, Ph.D. (Medical Sciences), Assistant of the Obstetrics and Gynecology Department, Institute of Postgraduate Education Ivano-Frankivsk National Medical University Nazar Matviykiv, Ph.D.(Medical Sciences), Assistant of the Obstetrics and Gynecology Department Institute of Postgraduate Education Ivano-Frankivsk National Medical University

\section{FORMATION OF HEALTHY LIFESTYLE OF CHILDREN- THE PRIORITY TASK OF PARENTS}

The article notes that because of the threatening state of Ukrainian population health, the formation of a healthy lifestyle for children is of great importance. According to statistics, $90 \%$ of preschool children, pupils, students have some kind of deviations from health. According to the WHO, 2/3 of adult illnesses result from an unhealthy lifestyle in childhood. It was noted that only joint actions of the government, doctors, teachers, parents and the public can save the population from extinction. In the pedagogical scientific literature, the role of the state, the pedagogical and medical community in solving this problem is well covered. On the other hand, the task of parents on the formation of a healthy lifestyle in their children has been somewhat less studied.

The article, based on the requirements of international and national documents concerning the formation of a healthy lifestyle for children, explores the ways and methods of overcoming the challenges of our time by parents, which negatively affect the health of children. These documents include: the UN Convention on the Rights of the Child, the national program "National Action Plan for the Implementation of the UN Convention on the Rights of the Child" for the period up to 2016, Resolution of the Cabinet of Ministers of Ukraine dated May 30, 2018 No. 453 "On Approval of the State Social Program" National Plan actions for the implementation of the UN Convention on the Rights of the Child (for the period up to 2021), the National Program "Children of Ukraine", the law of Ukraine "Fundamentals of Ukrainian Legislation on Health Care", the Sanitary Regulations for General Secondary Education Institutions (introduced from 01.01.2021), etc. It was emphasized that the introduction of the last document gives rise to a number of new serious tasks for parents and parental committees of schools to organize the sanitary and medical safety of the educational environment.

The article notes that the establishment of a system of socio-economic incentives for persons leading a healthy lifestyle, provided for in Article 32 of the Law of Ukraine "Fundamentals of Ukrainian legislation on 
healthcare", has not yet happened. The example of the Republic of Uzbekistan, which introduced such incentives in 2018, can accelerate the introduction of this innovation in Ukraine.

Keywords: healthy lifestyle; public health; health education; UN Convention on the Rights of the Child; Children of Ukraine program; electronic devices; good nutrition; kinship; healthy skills; Sanitary Regulations; socio-economic incentives.

$\Pi$ остановка проблеми. Понад 15 тисяч шкідливих факторів навколишнього середовища, серед яких - забруднене повітря, неякісна вода, низькоякісні харчові продукти, інфекційні збудники, негативно впливають наздоров'я дітей. Шкодять здоров'ю дітей надмірне використання електронних пристроїв, недостатня рухова активність, нераціональне харчування, низький рівень оволодіння санітарно-гігієнічними навичками тощо. Внаслідок цього лише 3-5 \% дітей, які закінчують школу, можуть уважатися повністю здоровими! "Особливо зросла поширеність захворювань ендокринної, травної, сечостатевої систем, систем кровообігу і дихання. Збільшується кількість випадків захворювань, які раніше були характерними тільки для дорослих або для старіючого організму” [6]. Тільки спільні дії держави, медиків, педагогів, батьків та громадськості зможуть урятувати населення від вимирання. У педагогічній пресі добре висвітлена роль держави, педагогічної та медичної громадськості у розв'язанні цієї проблеми. Дещо слабше досліджуються шляхи та методи подолання впливу негативних викликів сучасності на формування здорового способу життя дітей їхніми батьками.

Аналіз останніх публікацій і досліджень. Зміст поняття “здоровий спосіб життя”, форми i методи формування здорового способу життя учнівдосліджувалиМ. Амосов[1],В. Сухомлинський[17], О. Вишневський [3], О. Ващенко [2], В. Горощук [4], Т. Надім'янова [12], А. Заікін [7] та інші.

Здоровий спосіб життя дорослого населення має певний економічний ефект. “...профілактика неінфекційних захворювань у 2,7 раза менш затратна, ніж лікування хворих. При цьому здоровий спосіб життя населення у 5 разів ефективніший, ніж лікувально-діагностична діяльність галузі охорони здоров'я, пов'язана із збереженням та зміцненням здоров'я населення" [8].

Мета статті. Дослідити шляхи і методи подолання негативного впливу сучасного суспільства на формування здорового способу життя дітей їх батьками, а також методи здійснення контролю батьків та батьківських комітетів за виконанням державних програм про формування здорового способу життя дітей, зокрема Санітарного регламенту для закладів загальної середньої освіти, затвердженого наказом МОЗ України №2205 від 25.09.2020 p.
Виклад основного матеріалу. Народна мудрість говорить: "Гроші втратив - нічого не втратив, час втратив - багато втратив, здоров'я втратив - все втратив". Тривогу громадськості викликає той факт, що частина учнівської молоді нехтує народною мудрістю і вживає наркотики, палить, передчасно вступає у статеві відносини. Це призводить до того, що значна частина учнів за станом здоров'я належать до спеціальних медичних груп.

Людина сьогодні звикла сподіватися не на захисні сили свого організму, а на могутність медицини. Академік Амосов стверджував: "Щоб бути здоровим, потрібні власні зусилля, постійні і значні. Замінити їх не можна нічим" [1].

Нагадаємо спочатку статтю 32 під назвою "Сприяння здоровому способу життя населення" Закону України "Основи законодавства України про охорону здоров' 'я":

“Держава сприяє утвердженню здорового способу життя населення шляхом поширення наукових знань 3 питань охорони здоров'я, організації медичного, екологічного і фізичного виховання, здійснення заходів, спрямованих на підвищення гігієнічної культури населення, створення необхідних умов, в тому числі медичного контролю, для заняття фізкультурою, спортом і туризмом, розвиток мережі лікарськофізкультурних закладів, профілакторіїв, баз відпочинку та інших оздоровчих закладів, на боротьбу із шкідливими для здоров'я людини звичками, встановлення системи соціальноекономічного стимулювання осіб, які ведуть здоровий спосіб життя" [8].

Потім ця стаття була доповнена:

"В Україні проводиться державна політика обмеження куріння та вживання алкогольних напоїв. Реклама тютюнових виробів, алкогольних напоїв та інших товарів, шкідливих для здоров'я людини, здійснюється відповідно до Закону України “Про рекламу".

“3 метою запобігання шкоди здоров’ю населення застосування гіпнозу, навіювання, інших методів психологічного і психотерапевтичного впливу дозволяється лише у місцях та в порядку, встановлених центральним органом виконавчої влади, що забезпечує формування державної політики у сфері охорони здоров'я"' [8].

Україна взяла на себе низку зобов'язань із поліпшення добробуту дітей, зокрема, підписавши 
Конвенцію ООН про права дитини [9]. Ця Конвенція була ратифікована Постановою Верховної Ради України № 789-ХІІ від 27 лютого 1991 р. та набула чинності для України 27 вересня 1991 р. Крім того, у 2003 та 2005 р. відповідно український Парламент ратифікував два факультативні протоколи до Конвенції про права дитини щодо торгівлі дітьми, дитячої проституції і дитячої порнографії та щодо участі у збройних конфліктах, які з того часу стали частиною національного законодавства.

Серед завдань сімейного виховання Конвенція (ст.18) вимагає, щоб “докладалися всі можливі зусилля до того, щоб забезпечити визнання принципу загальної та однакової відповідальності обох батьків за виховання і розвиток дитини. Батьки, або у відповідних випадках законні опікуни, несуть основну відповідальність за виховання і розвиток дитини. Найкращі інтереси дитини є предметом їх основного піклування" [9].

Принциповою у забезпеченні прав дітей на виховання є ст. 29 цього документа. Практично в ній регламентуються для країн-учасниць пріоритети мети суспільного виховання: розвиток особи, талантів, розумових і фізичних здібностей дитини; виховання поваги до прав людини і основних свобод, до батьків дитини, ії культурної самобутності, мови та цінностей країни, до навколишнього середовища, природи; підготовку дитини до свідомого життя у вільному суспільстві в дусі розуміння, миру, терпимості, рівноправності чоловіків і жінок і дружби між усіма народами, етнічними, національними і релігійними групами [9].

Професор М. Щербань зазначає: "Хто $з$ нас, навіть 3 працівників освіти, знає Конвенцію ООН про права дитини? Хто в Україні здійснює нагляд за дотриманням іiі вимог? Відповідь може бути лише одна - ніхто! Тим, хто знає іії зміст, можна лише мріяти про те, щоб цей документ став ціннісним орієнтиром уряду, батька і матері, кожної людини, що займається здоров'ям, навчанням і вихованням дітей. Конституція має стати основним законом життя і взаємин дорослих і дітей” [20].

Таким чином, держава має сприяти батькам у формуванні у дітей здорового способу життя. Насправді, ситуація зовсім інша. Той самий автор ще 1995 р. у тій же статті констатував: “Іде процес знищення позашкільних закладів, того, що раніше звалось будинками піонерів, станціями юних техніків, натуралістів, туристів, клубами за інтересами, дитячими клубами при ЖЕКах, все передається в оренду або продається комерційним структурам - звужується простір дитячого життя, за що нам доведеться відповідати знищенням самих себе - свого майбутнього. Приватизація дитячих виховних закладів - аморальне явище, злочин дорослих перед дітьми" [20].

Тільки спільні дії держави, медиків, педагогів, батьків та громадськості зможуть урятувати націю від вимирання. У педагогічній пресі добре висвітлена роль держави, педагогічної та медичної громадськості у розв'язанні цієї проблеми. Дещо слабше описані завдання батьків щодо формування у їх дітей навичок здорового способу життя.

Загальнодержавна програма "Національний план дій щодо реалізації “Конвенції ООН про права дитини” на період до 2016 р., була затверджена Законом України від 5 березня 2009 р. № 1065 [13]. Метою програми визначено створення умов для утвердження в суспільстві сімейних цінностей, матеріального забезпечення сімей $з$ дітьми, забезпечення їх морального здоров'я, виховання відповідального батьківства та запобігання соціальному сирітству. Для досягнення цієї мети слід підвищити рівень народжуваності, подолати бідність серед дітей та сімей 3 дітьми, посилити соціальний захист, розробити та впровадити системи підготовки дітей і молоді до сімейного життя та відповідального батьківства та ін. [13].

Кабінет міністрів України 30 травня 2018 р. прийняв постанову № 453 "Про затвердження Державної соціальної програми "Національний план дій щодо реалізації Конвенції ООН про права дитини" на період до 2021 р."

Першим на допомогу сім'ї, в якій появилося новонароджене дитя, має прийти дитячий лікар. Він повинен повністю взяти на себе обов'язки щодо допомоги батькам, зокрема молодим, щодо догляду за дитиною.

Батькам слід налагодити взаємодію - батько (чи мати) - дитина. Заслужений учитель України Н. Скрипченко дала поради вчителям щодо ведення розмов учителя з учнем. Через те, що ці поради $є$ корисними і для батьків, то наведемо деякі з них:

“Для роз'яснення неправильних уявлень чи незавершених думок використовувати метод типу: “Що ти можеш мені розповісти про..?”. “Розкажи про свій малюнок”. “Вислови свою думку щодо кольорів малюнку...”. “Дати час і змогу дитині розповісти про це все, про свою роботу. Поговорити з дитиною про те, що вона відчуває , і що вона хоче висловити" [17].

Автор статті розкриває і деталі такої розмови:

“Сісти на рівні $з$ дитиною так, щоб вона могла дивитися вам у очі і ваша взаємодія носила 
особистий характер. Говоріть неголосно. Діти здебільшого реагують прихильно на нормальний тон голосу, а не на крик. Приємний голос справляє заспокійливий пом'якшуючий ефект. За зразок своєї мови візьміть наступне правило: повні речення, короткі речення, прості речення. Використовуйте повторення і розширення. Повторюйте, поправляйте дитину та доповнюйте звичайним тоном голосу. Ставтесь прихильно до почуттів дітей, до їх ідей. "Мені подобається, як ти використав жовтий колір у своєму малюнку”, “О я бачу, що у тебе багато ідей!”, “Молодець, добре міркуєш! ... Уникайте запитань, на які можна відповісти одним словом “так” або “ні”... Розвивайте словниковий запас для характеристики почуттів ...пояснюйте дітям значення слів. Ставте дітям запитання для того, щоб дізнатися про рівень їх розуміння.... Почуття власної цінності, гідності і здорової поваги до себе у дітей розвивається на основі досвіду любові, прихильості з боку батьків, учителів та ровесників. Почуття впевненості в тому, що ії люблять, є тим фундаментом, на якому дитина будує власну любов до інших людей” [17].

Торкнемося ще однієї проблеми у формуванні здорового способу життя дітей і підлітків використання дітьми електронних пристроїв. У наукових працях та періодичній пресі є різні думки щодо користі та шкоди цього. Батьки повинні враховувати, що Інтернет міцно увійшов у наше життя, і ми почуваємося безпорадними, коли він зникає. Крім того, навіть уявити собі не можемо, яким буде цифровий світ через кілька років. Отже, діти мають бути підготовлені до життя у такому світі. Ми дотримуємося думки, що батьки при використанні електронних пристроїв між шкодою і користю повинні вибрати золоту серединку. Цією серединкою є обмежене використання дітьми гаджетів. Лікарі рекомендують такі терміни щоденного користування дітьми гаджетів: діти 45 років - не більше 15 хвилин; 6 років - 20 хвилин; 7-9 років - 30 хвилин; $10-12$ років - 40 хвилин; 13-14 років - 50 хвилин [5].

Щоб дитині уникнути короткозорості, оптимальна відстань між ії очима і монітором має бути 60-70 см, але за умови, що знаки і картинки не дуже дрібні. Батькам слід використовувати додатки з функції батьківського контролю, яка дозволяє обмежувати час використання електронного пристрою або заблокувати доступ до певних сайтів. Батьки можуть роз'яснити дітям потребу у чергуванні занять з електронними пристроями і рухливими іграми, прогулянками, читанням книг. Корисною як для дітей, так і для дорослих є гімнастика для очей. Батьки можуть запровадити для дітей раз на тиждень “день без смартфону” і придумати для них цікаві ігри, веселі заняття і т.ін. Можливо, дітям це сподобаається, і вони захочуть “дні без смартфону” проводити частіше [5].

У поняття здорового способу життя входить $\mathrm{i}$ раціональне харчування О. Миколюк підкреслює вплив харчування у дитячому віці на здоров'я дорослої людини: “За даними ВООЗ 2/3 хвороб у дорослому віці виникають внаслідок нездорового способу життя в дитинстві, - розповів Олег Швець (кандидат медичних наук, головний позаштатний дієтолог МО3 України - авт.). За даними дослідження, яке провели в Україні торік (2010), належну кількість овочів і фруктів (більше одного разу на день) уживають тільки 22 \% та 17 \% відповідно. Не набагато краща ситуація із споживанням молочних продуктів та цільних злаків: лише $1 / 3$ школярів повідомили про достатній рівень їх уживання. За даними річної статистичної звітності МОЗ України (2009), понад два мільйони українських дітей страждають на хвороби, пов'язані з нездоровим харчуванням" [11].

О. Миколюк попереджує про одну небезпеку для дітей - надмірне споживання солодощів, особливо у святкові та передсвяткові дні: “ на думку стоматологів, найбільшу шкоду емалі зубів завдають саме “смоктульки”: вони роз'їдають зубну емаль. Лікарі радять після того, як дитина з'їла цукерку, обов'язково прополоснути рот, адже одним із факторів, які провокують карієс, $\epsilon$, за словами стоматологів, “вуглеводні залишки в порожнині рота”. I, звичайно, систематично чистити зуби зранку і ввечері [11].

Батьки повинні роз'яснювати дітям, що захоплення солодкими продуктами може викликати у них важке захворювання - цукровий діабет. Лікарі радять включати до дитячих подарунків горіхи, родзинки, курагу, яблука та інші фрукти.

31 січня 2021 р. набуде чинності “'Санітарний регламент для закладів загальної середньої освіти", затверджений наказом МО3 України №2205 від 25.09.2020 р. У ньому зазначаються медичні вимоги безпеки до освітнього середовища, а саме:

- санітарно-гігієнічні норми влаштування території;

- гігієнічні вимоги до будівель її приміщень системи забезпечення життєдіяльності;

- забезпечення освітнього процесу;

- забезпечення харчування;

- організація медичного обслуговування та формування гігієнічних навичок та засад здорового способу життя; 
- вимоги до санітарного і спеціального одягу та особистої гігієни працівників закладу освіти, інших осіб, залучених до організації харчування [20].

Дотримання цих вимог суттєво допоможе батькам у формуванні здорового способу життя дітей. Батьки і батьківські комітети шкіл зацікавлені у повному виконанні Санітарного регламенту і через те повинні здійснювати повсякденний контроль за його реалізацією.

Проблема формування здорового способу життя не може бути успішно розв'язаною без уваги до духовної і моральної основи суспільства - сім'ї. Людство розглядає сім'ю як зернину, з якої проростає життя. За рішенням 47-ої сесії Генеральної Асамблеї ООН з 1994 року 15 травня відзначається як Міжнародний день сім'ї. Щорічне святкування Міжнародного дня сім'ї має привернути увагу держав i урядів до життедіяльності родин у сучасному світі. Кожен рік для Міжнародного дня сім’ї вибирається тема. Одного разу була вибрана тема: “Сім'я, здоровий спосіб життя і стійке майбутнє”.

Національна програма “Діти України” - це комплексний документ, у якому відповідно до положень Конвенції ООН про права дитини, ратифікованої Україною, визначено основні напрями державної політики щодо дітей та заходи з її реалізації як органами влади різного рівня, так і різними установами, організаціями і суспільними інститутами, серед яких одне 3 провідних місць посідає сім’я. Програму “Діти України” було затверджено на виконання Указом Президента України ще 18 січня 1996 р.

3 огляду на те, що термін виконання програми було встановлено 1996 - 2000 pp., а значна частина ії заходів має довгостроковий характер та їх виконання триває, було видано Указ Президента України "Про основні заходи щодо забезпечення виконання Національної програми “Діти України” на період до 2005 р.” від 24 січня 2001 р., метою та основними завданнями яких $\epsilon$ створення умов для фізичного, інтелектуального і духовного розвитку дітей, забезпечення їх соціального захисту та належного виховання, яке грунтується на здобутках українського національного та світового культурно-історичного розвитку.

У п.1.4. Національної програми “Діти України” сказано:

“Сім'я є і залишається природним середовищем для фізичного, психічного, соціального і духовного розвитку дитини, Її матеріального забезпечення і несе відповідальність за створення належних умов для цього. Вона має виступати основним джерелом матеріальної та емоційної підтримки, психологічного захисту, засобом збереження і передачі національно-культурних і загальнолюдських цінностей прийдешнім поколінням. У першу чергу сім'я повинна залучати дітей до освіти, культури i прищеплювати загальнолюдські норми суспільного життя. Основними методами збереження та зміцнення здоров'я в умовах сім'ї мають стати профілактика захворювань та дотримання певних гігієнічних правил у повсякденному житті, оптимальна фізична активність, загартування організму, повноцінне харчування, запобігання шкідливим явищам палінню, алкоголізму тощо.

Усі державні та суспільні інституції мають підтримувати зусилля батьків або осіб, які їх замінюють, спрямовані на забезпечення відповідних умов для виховання, освіти, розвитку здорової дитини" [13].

Керівник Центру здоров'я Державного інституту розвитку сім'ї та молоді Н. Романова висловила своє ставлення до державних програм: “В Україні прийнято 11 законів і державних програм, які так чи інакше стосуються здоров'я. Але більшість із них не спрацьовує ефективно, тому що проводяться просто заходи, розраховані на великий загал. А для результату потрібно включати індивідуальну роботу, тому треба розробляти ідеологію щодо здорового способу життя на індивідуальному рівні. Маємо працювати на двох рівнях, зокрема на державному, коли мова йде про концепцію щодо здорового способу життя, яка поки що не прийнята.

Існують програми від Міністерства у справах сім’і, молоді та спорту, Міністерства охорони здоров'я, але вони не включають формування здорових навичок. Також треба формувати молодіжні субкультури" [19].

У Державному інституті розвитку сім’ї та молоді діє програма "Молодіжні тренінгові студії з числа студентської молоді”, розпочата 1996 р. Вона створювалася як експериментальна школа для молодих науковців, спеціалістів та студентів, яких цікавлять програми здорового способу життя і які можуть пропагувати це в соціумі. Для цього вони проводять дослідження, організовують тренінги та працюють безпосередньо в школах, ЗВО та коледжах з молоддю [19].

Серед загальнолюдських норм суспільного життя О. Вишневський виділяє родинність: "Міцна родина - міцне суспільство. Але, щоб людина прагнула побудувати міцну родину, недостатньо лише основного інстинкту. Вона потребує ще у дитинстві, пізнати позитивний досвід родинного 
співжиття-не “садиківського" (“колективістського"), а саме родинного. Отож, у сім’ї двоєдине завдання: виховання громадянина (в широкому розумінні) $\mathrm{i}$ прищеплення дитині схильності до родинного життя, виховання сім'янина. Це різні завдання: громадянин може виховатись у садку, а сім'янин - лише у родині" [3].

Важливим завданням батьків $є$ проведення 3 дітьми санітарно-просвітницької роботи, зокрема на такі теми:

- як уберегтися від інфекційних захворювань у школі;

- як дотримуватись гігієни рук;

- про гігієну харчування;

- про особисту гігієну;

- про дотримання вимог карантину під час пандемії.

При потребі можна запросити медиків для проведення бесід на ці теми з батьками на класних батьківських зборах або з учнями в класі.

У статті 32 Закону України “Основи законодавства України про охорону здоров'я” передбачено “встановлення системи соціальноекономічного стимулювання осіб, які ведуть здоровий спосіб життя" [8]. У засобах масового інформування відсутня інформація про випадки такого стимулювання або існування такої системи. Але є досвід інших країн, зокрема Узбекистану, про впровадження плати громадянам за здоровий спосіб життя.

1 листопада 2018 р. Президент Республіки Узбекистан підписав указ "Про заходи щодо широкого впровадження здорового способу життя і дальшого розвитку масового спорту”. На виконання цього указу створена платформа “Здоровий спосіб життя” що передбачає за виконання вимог здорового способу життя громадянам Узбекистану віком від 18 років і старше на їх електронні гаманці будуть нараховуватись певні грошові кошти [15].

Висновки. Щоб вийти із загрозливого стану здоров'я населення, потрібні спільні зусилля держави, медиків, педагогів, батьків та громадськості. Виходячи з вимог міжнародних та державних документів, досліджуються шляхи та методи подолання викликів сучасності, які негативно впливають на формування здорового способу життя дітей. Стверджується, що впровадження 31 січня 2021 р. Санітарного регламенту загальноосвітніх навчальних закладів України викликає появу нових серйозних завдань для батьків та батьківських комітетів закладів освіти. Досліджується проблема соціальноекономічного стимулювання громадян, які дотримуються здорового способу життя. Адже профілактика захворювань та дотримання громадянами здорового способу життя дає державі відчутний економічний ефект. Приклад Республіки Узбекистан щодо такого стимулювання може прискорити його введення $\mathrm{i}$ в Україні.

\section{ЛІТЕРАТУРА}

1. Амосов М. Роздуми про здоров'я. Київ, 1990. T. 1. 624 c.

2. Ващенко О. Методика організації здоров'язбережувального освітнього середовища початкової школи. Наук. вісник Ужгородського національного університету. Серія Педагогіка. Соціальна робота. 2014. Вип. 32. С. 34-36.

3. Вишневський О. Українська педагогіка на перехресті двох світоглядів. Освіта. 2007. 19 - 26 грудня. С. 4-5.

4. Горащук В. П. Культура здоровья спортсмена и ее сущность. Педагогіка, психологія та медико-біологічні проблеми фізичного виховання і спорту. Харків, 2004. № 1. С. 64-73.

5. Горська А. Чи шкодять сучасні гаджети дітям? Поради для батьків.URL: https:// www.projectkesher.org.ua/.../chy-shkodiat-suchasnihadzhety-ditiam- porady-dlia-bat-kiv/

6. Грицюк M. I., Навчук I. В. Здорові діти здорова нація. URL: https://www.bsmu.edu.ua/blog/ 6791-zdorovi-diti-zdorova-natsiya/

7. Заікін А.В. Основні аспекти виховання здорового способу життя підлітків в умовах дитячо-юнацької спортивної школи. Вісник Кам'янець-Подільського наиіонального університету імені Івана Огієнка. Фізичне виховання, спорт $і$ здоров'я людини. № 8. 2017. С. 102-104.

8. Закон України “Основи законодавства України про охорону здоров'я” (від 8.09.2019 №1507). URL: https://zakon.rada.gov.ua/laws/show/ 2801-12

9. Конвенція ООН про права дитини. URL: https://zakon.rada.gov.ua/laws/show/995 021

10. Концепція Загальнодержавної програми “Здоров’я - 2020: український вимір”, схвалена розпорядженням Кабінету Міністрів України від 31 жовтня 2011 р. № 1164.

11. Миколюк О. Здорових свят! День. 2011. 29 грудня.

12. Надім'янова Т. Вплив школи і сім'ї у формуванні основ здорового способу життя молодшого школяра. Актуальні питання гуманітарних наук. 2015. Вип. 14. С. 283-288. URL: http://nbuv.gov.ua/UJRN/apgnd-2015-14-41.

13. Національна програма "Діти України", затверджена Указом Президента України від 18 січня 1996 року № 63/96 
14. "Національний план дій щодо реалізації Конвенції ООН про права дитини” на період до 2021 року, затверджений постановою Кабміну України № 453 від 30.05.2018 p. URL: https:// zakon.ra da.gov.ua/go/453-2018-п.

15. Про заходи щодо широкого впровадження здорового способу життя і дальшого розвитку масового спорту. Указ Президента Республіки Узбекистану від 1 листопада 2018 року. URL: https://www.radiosvoboda.org/a/newsuzbekystan...za.../30928629.html.

16. Санітарний регламент для закладів загальної середньої освіти, затверджений наказом МО3 України №2205 від 25.09.2020 p.

17.Скрипченко Н., Савченко О.Я., Волошина Н.Й. Читанка $4 / 3$ класи для чотириріч. почат. шк. 4-те вид., перероб. Київ, 1995. 364 с.

18. Сухомлинський В. Батьківська педагогіка. Київ, 1978.263 с.

19.Філіпенко I. Бути здоровим - модно. Шкільний світ. 2009. №42. С.7-9.

20. Щербань М. Педагогічні основи правової культури вчителя і керівника навчального закладу. Педагогічна культура вчителя: навч. посіб. Київ, 2010. С. 90-115.

\section{REFERENCES}

1. Amosov, M. (1990). Rozdumy pro zdorovia [Reflections on health]. Kyiv. Vol. 1. 624 p. [in Ukrainian].

2. Vashchenko, O. (2014). Metodyka orhanizatsii zdoroviazberezhuvalnoho osvitnoho seredovyshcha pochatkovoi shkoly [Methods of organizing a healthy educational environment of primary school]. Scientific Bulletin of Uzhhorod National University. Pedagogy series. Social work. Vol. 32. pp. 34-36. [in Ukrainian].

3.Vyshnevskyi, O. (2007). Ukrainska pedahohika na perekhresti dvokh svitohliadiv [Ukrainian pedagogy at the crossroads of two worldviews]. Education. December 19 - 26. pp. 4-5. [in Ukrainian].

4. Horashchuk, V. P. (2004). Kultura zdorovya sportsmena i ee sushchnost [Athlete's health culture and its essence]. Pedagogy, psychology and medical and biological problems of physical education and sports. Kharkiv. No. 1. pp. 64-73. [in Russian].

5. Horska, A. Chy shkodiat suchasni hadzhety ditiam? Porady dlia batkiv [Do modern gadgets harm children? Tips for parents.]. Available at: https:// www.projectkesher.org.ua/.../chy-shkodiat-suchasnihadzhety-ditiam- porady-dlia-bat-kiv/[in Ukrainian].

6. Hrytsiuk, M. I. \& Navchuk, I. V. Zdorovi dity - zdorova natsiia [Healthy children - healthy nation]. Available at: https://www.bsmu.edu.ua/blog/6791zdorovi-diti-zdorova-natsiya/[in Ukrainian].
7. Zaikin, A.V. (2017). Osnovni aspekty vykhovannia zdorovoho sposobu zhyttia pidlitkiv $\mathrm{v}$ umovakh dytiacho-yunatskoi sportyvnoi shkoly [The main aspects of educating a healthy lifestyle of adolescents in the children's and youth sports school]. Bulletin of Kamyanets-Podilskiy Ivan Ohiyenko National University. Physical education, sports and human health.No. 8. pp. 102-104. [in Ukrainian].

8. Zakon Ukrainy "Osnovy zakonodavstva Ukrainy pro okhoronu zdorovia" (vid 8.09.2019 №1507). [Law of Ukraine "Fundamentals of the legislation of Ukraine on health care" (from 8.09.2019 №1507)]. Available at: https://zakon.rada.gov.ua/laws/ show/2801-12 [in Ukrainian].

9. Konventsiia OON pro prava dytyny [UN Convention on the Rights of the Child]. Available at: https://zakon.rada.gov.ua/laws/show/995_021[in Ukrainian].

10. Kontseptsiia Zahalnoderzhavnoi prohramy "Zdorovia-2020: ukrainskyi vymir" [Concept of the National Program "Health - 2020: the Ukrainian dimension"], approved by the order of the Cabinet of Ministers of Ukraine of 31 October 2011. No. 1164. [in Ukrainian].

11. Mykoliuk, O. (2011). Zdorovykh sviat! [Healthy holidays!]. Day. December 29. [in Ukrainian].

12. Nadimianova, T. (2015). Vplyv shkoly i simi u formuvanni osnov zdorovoho sposobu zhyttia molodshoho shkoliara [The influence of school and family in the formation of the foundations of a healthy lifestyle of primary school students]. Topical issues of the humanities. Vol. 14. pp. 283-288. Available at: http://nbuv.gov.ua/UJRN/apgnd-2015-14-41. [in Ukrainian].

13. Natsionalna prohrama "Dity Ukrainy", zatverdzhena Ukazom Prezydenta Ukrainy vid 18 sichnia 1996 roku № 63/96 [National program "Children of Ukraine"], approved by the Decree of the President of Ukraine from 18 January 1996 No. 63/96 from 18 January 1996 No. 63/96].[in Ukrainian].

14. "Natsionalnyi plan dii shchodo realizatsii Konventsii OON pro prava dytyny" na period do 2021 roku, zatverdzhenyi postanovoiu Kabminu Ukrainy № 453 vid 30.05.2018 r. ["National Action Plan for the Implementation of the UN Convention on the Rights of the Child" for the period up to 2021, approved by the Cabinet of Ministers of Ukraine].No. 453 from 30.05.2018]. Available at: https://zakon.ra da.gov.ua/go/453-2018-p. [in Ukrainian].

15. Pro zakhody shchodo shyrokoho vprovadzhennia zdorovoho sposobu zhyttia i dalshoho rozvytku masovoho sportu. Ukaz Prezydenta Respubliky Uzbekystanu vid 1 lystopada 2018 roku [About measures for wide introduction of a healthy way of 
life and further development of mass sports. Decree of the President of the Republic of Uzbekistan of November 1, 2018]. Available at: https:// www.radiosvoboda.org/a/news-uzbekystan...za.../ 30928629.html. [in Ukrainian].

16. Sanitarnyi rehlament dlia zakladiv zahalnoi serednoi osvity, zatverdzhenyi nakazom MOZ Ukrainy №2205 vid 25.09.2020 r. [Sanitary regulations for general secondary education institutions, approved by the order of the Ministry of Health of Ukraine].No. 2205 from 25.09.2020]. [in Ukrainian].

17. Skrypchenko, N., Savchenko, O.Ia. \& Voloshyna, N.I. (1995). Chytanka 4/3 klasy dlia chotyryrich. pochat. shk. [Reader $4 / 3$ classes for four-year primary school]. 4th ed., Reworked.Kyiv, 364 p. [in Ukrainian].

18. Sukhomlynskyi, V. (1978). Batkivska pedahohika [Parental pedagogy]. Kyiv, 263 p. [in Ukrainian].

19. Filipenko, I. (2009). Buty zdorovym - modno [Being healthy is fashionable]. School world. No.42. pp.7-9. [in Ukrainian].

20. Shcherban, M. (2010). Pedahohichni osnovy pravovoi kultury vchytelia i kerivnyka navchalnoho zakladu [Pedagogical bases of legal culture of the teacher and the head of educational institution]. Pedagogical culture of the teacher: textbook. Kyiv, pp. 90-115. [in Ukrainian].

Стаття надійшла до редакції 14.10.2020

УДК 78:373.5 (477.64)

DOI:

Вікторія Мітлицька, кандидат мистецтвознавства, професор Дніпропетровської академї музики імені М. Глінки

\section{МУЗИЧНА ОСВІТА В ЗАГАЛЬНООСВІТНІХ ЗАКЛАДАХ ЗАПОРІЗЬКОГО КРАЮ (кінець XIX - початок XX ст.)}

У статті проаналізовано становлення музичної освіти у Бердянському, Мелітопольському й Олександрівському повітах, щзо відповідають нинішньому уявленню про Запорізький край. Виокремлено один із освітніх сегментів регіону - загальноосвітні заклади, щуо становили вагому складову сукупного музичноосвітнього “продукту”. Виявлено особливості музичної освіти в циих закладах. Встановлено аналогію певних типів концертів за участю учнів з концертами у столичних містах. Зроблено висновок про домінування у музично-освітньому прочесі повітових середніх шкіл хорової форми з епізодичним вкрапленням інструментально-виконавської форми.

Ключові слова: музична освіта; початкові школи; середні освітні заклади; Запорізький край; хоровий спів, інструментальне виконавство.

תim. 19.

Viktoriya Mitlytska, Ph.D.(Study of Art), Professor of the Piano Department Dnipro Mykhaylo Hlinka Akademy of Music

\section{MUSIC EDUCATION IN THE GENERAL EDUCATIONAL INSTITUTIONS OF ZAPORIZHZHYA REGION (late 19th - early 20th century)}

The article systematizes and analyzes the formation of music education in Berdyansk, Melitopol and Alexander counties, which were part of Katerynoslav and Tavriya provinces. These counties territories did not then form a single administrative unit. Their combination corresponds to our current idea of Zaporizhzhya region. Moderate rates of industrial development, agricultural production and remoteness from the provincial centers (Katerynoslav and Simferopol) have determined the peculiarities of the formation of music education in this region. Here music education, as an integral part of general education, developed in the county secondary schools. However, only primary schools en masse enrolled students. There were about a hundred of them in Oleksandrivsk County. The primary school rate was higher in the settlements of Mennonites and German colonists in Melitopol and Berdyansk countries. There were eight, five and three secondary schools in these counties, respectively. Common features are characteristic of the secondary schools' educational process. It is the study of church singing, the basics of music literacy and the school choirs' organization in primary schools. The functioning of orchestras and instrumental ensembles was a unifying factor in music education in county secondary schools. Participation in cultural events, city celebrations and concerts was defined as the most common forms of the level music knowledge and instrumental playing manifestation' skills of the secondary educational institutions' pupils in the region. The similarity of concerts with the students participation' certain types is established on the factual material basis in the provincial musiceducational practice. On the factual basis in the provincial educational music practice, the certain analogy of concerts' types with the students' participation and concerts in the capitals is established. This corresponded to the 